\title{
自治体向けGIS導入マニュアル作成準備作業
}

田中公雄、今井 修、大場 亨、中村秀至、玉川英則

\section{Preparatory Work about a GIS Manual for Local Governments}

Kimio TANAKA, Osamu IMAI, Tohru Ohba, Hideji Nakamura, and Hidenori Tamagawa

\begin{abstract}
Following to the past research about the concerning level of GIS for local governments, we discussed the problems of unfamiliar for GIS. As a result, the further research was collecting the GIS specifications from local governments already introduced. The 22 of 33 selected local governments were sending the papers.

Viewpoints of this analysis were, 1. Recommended field for GIS application, 2. The data model of GIS, 3. CB analysis of GIS, and 4. Organization and training. The status of analysis was ongoing, and we will publish next year by many discussions of local government persons.
\end{abstract}

Keywords: 地方自治体、データの共同利用、GIS普及

1.はじめに

自治体 S I Gでは、既報（理論と応用、3 巻 1 号）した全国調査に引き続き、複数業務で利用可能 な G I Sの普及に向けた第 2 段階の作業に入った (図 1)。

本 S I Gでは作業グループを編成し、2 で述べる事 例システム基本計画書の分析と、これをべースにし て自治体向けG I S 導入マニュアル（構成案 困 2）のドラフト作成に着手している。導入マニュア ルは全部で 6 パートからなり、それぞれ次ぎの内容 が書き込まれる。

(1)「今、なぜG I Sか」は、特に自治体上層部に G I S を理解させるためのプレゼンテーションのガ イドである。GＩＳには相当の出費を伴なうため、 トップの理解は絶対的に必要である。そのため担当 者をその気にさせるのとは違った面からアプローチ したい。

(2)「G I Sによる業務処理」(3)「G I Sのデータ 構造」は担当者が仕様書を作るための手引きであ

田中： $\bar{T} 124$ 東京都葛飾区立石 5-13 葛飾区役所

Katsushika Ward Office.

5-13 Tateishi, Katsushika, Tokyo 124

Tel. 03-3695-1111

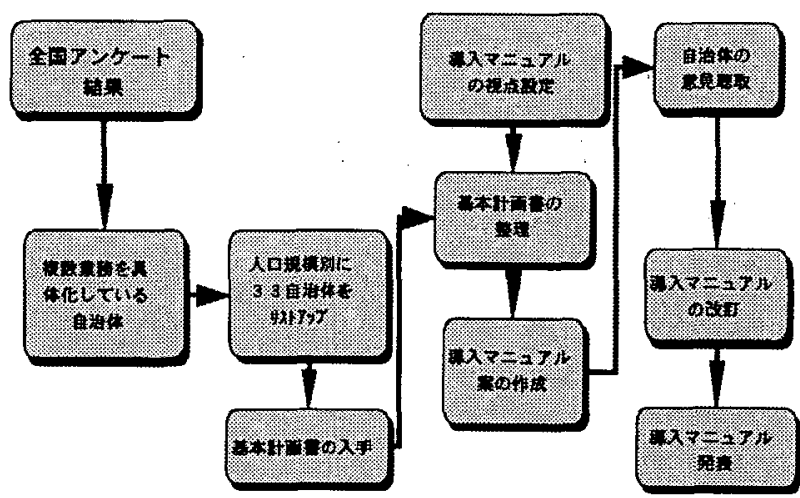

図 1 業務フロー

導入マニュアルの構成（案）

・今、なぜ $G$ । $S$ か

・ G I Sによる業務処理

・G I S のデータ構造

- GＩSの費用対効果

・推進組織と要員教育

・G।Sデータの流通

図 2 マニュアル構成案 
る。業務の各フェーズに要求されるシステム機能を 整理し、共通利用データベースの試案を提示する。

(4)「G I Sの費用対効果」は、予算部門説得の資 料づくりのノウハウを示し、(5)「推進組織と要員教 㕕」では開発から運用に至るまでの組織づくり人づ くりを論じ、(6)「G I S データの流通」では入手で きる外部データを解説し、自ら作成したデータ公開 の必要性と留意点に触れる。

現在(1)と(6)を除いて作業が進んでおり、ドラフト のまとまりの節目ごとに、S I G 全体会での検討、 自治体寒務者の意見聴取などによって補強し、来年 度中に完成させる予定である。

\section{2. 事例調查}

1 次調査で複数業務利用と回答のあった団体か ら、人口規模によって層化抽出した 33 団体に『シ ステム基本計画書』の提出を求め、 22 団体より提 出を受けた。その概要を表1に示す。

この内容は、上記マニュアルに事例として紹介さ れる。

表 1 基本計画入手団体

\begin{tabular}{|c|c|c|}
\hline 団体名 & 人口 (千人) & 対象業務 \\
\hline 利島村 & 0.3 & 地籍調査、税 \\
\hline 坂内村 & 0.7 & 地籍調査 \\
\hline 加計町 & 5 & 地籍調查 \\
\hline 焳木村 & 7 & 地籍調查 \\
\hline !!辺町 & 11 & 税. 我道：道路、都市計画 \\
\hline 久世町 & 12 & 土地総合（注 1） \\
\hline 聖籠町 & 13 & 土地課税 \\
\hline 勝山市 & 30 & 上下水道、防災 \\
\hline 美濃加茂市 & 44 & 上下水道、防災 \\
\hline 長浜市 & 56 & 税、水道、道路、都市計画 \\
\hline 城陽市 & 84 & 税、水道、都市計画、土木 \\
\hline 津山市 & 89 & 地籍調查、下水道 \\
\hline 東海市 & 98 & 土地家屋、消防 \\
\hline 市原市 & 273 & 都市計画 \\
\hline 西宮市 & 412 & 土地総合 (注 1) \\
\hline 倉敷市 & 422 & 土地総合（注 1) \\
\hline 松山市 & 456 & 土地総合（注 1) \\
\hline 岡山市 & 598 & 土地総合（注 1$)$ \\
\hline 世田谷区 & 757 & 道路、都市計画 \\
\hline 広島市 & 1077 & 都市計画 \\
\hline 川崎市 & 1171 & 都市郡画 \\
\hline 名古屋市 & 2091 & 土地総合（注 1) \\
\hline
\end{tabular}

注 1 : 土地総合とは土地情報をベースにした全庁的利 用体制を整備している団体

\section{3. 導入マニュアルの概要}

\subsection{GISによる業務処理}

基本計画書から抽出したG I S の応用が計画され ている業務内容と、そのシステム化に必要なG I S の機能を表 2 に示す。同じ業務に分類したもので あっても、システム化する範围によってGＩＳに要 求される機能は異なった。例えば、固定資産税分野 における土地評価業務では、地目別に各筆を色分け した地図を作るまでであれば、更新と表示の機能が あればよいが、価格形成要因等の解析まで行うに は、距離や面積の計測、オーバーレイといつた機能 が必要となる。

いずれの分野の台帳管理型の業務においても、図 形及び属性データの更新機能、属性の演算及び集 計、各種の地図表示機能が要求される。上水道、下 水道分野において下水道計画支援等の計画型業務ま でも指向している自治体では、これらの機能の他に ラインーポリゴンオーバーレイ機能、ポリゴンオー バーレイ機能も求められる。

市販されているG I Sソフトウェアにはそれぞれ 特色があり、施設管理型業務への使用を得意とする もの、固定資産評価業務への使用を得意とするも の、計画型業務への使用を得意とするものなどがあ る。各業務での共通利用を前提とせず、個別にシス テム開発を行おうとするときには、その業務に最も 適したGI Sソフトウェアが選択される。しかし、 前述のようにG I Sソフトウェアに要求される機能 はそれぞれの分野及び業務により異なるので、個別 にシステム開発を進めた場合には共通利用への展開 は一般に難しい。

GI S を採用していない特定行政庁である市にお いて建築物関係の業務に使用している地図や台帳類 の標準的なものを表 3 に示す。1 から 6 について は、建築設計業者が事前調査に来庁した際の法規制 等の検索システムを構築すると効果が大きい。7 以 降に関しては建築物の図形データを共通データベー スとし、各部署の既存の台帳データベースを属性 データとして利用する場合が多い。

ここで、建築確認申請受付台帳、建築物用途別現 況調査調書、住居番号設定簿、家屋課税台帳等の台 
表 2 GISの応用が計画されている自治体業務と必要なGISの機能

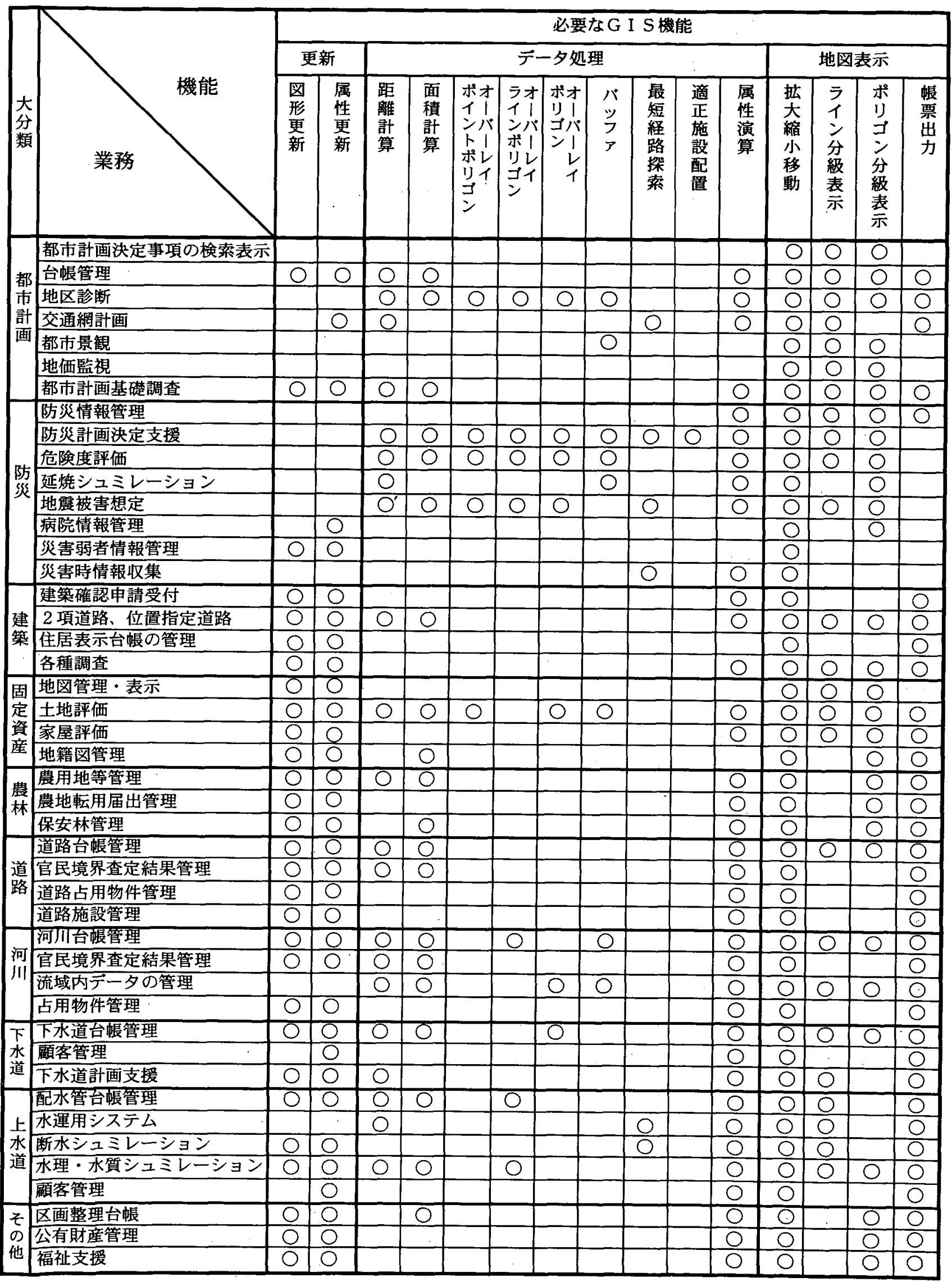


表3 自治体の建築物関保の業務で使用している地図、台帳

\begin{tabular}{|c|c|}
\hline 地国 & 調書·台帳類 \\
\hline 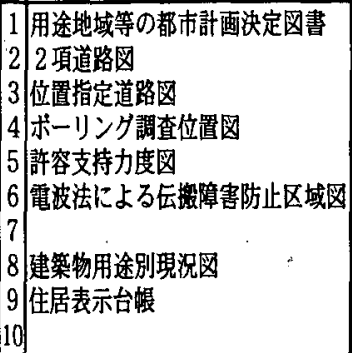 & 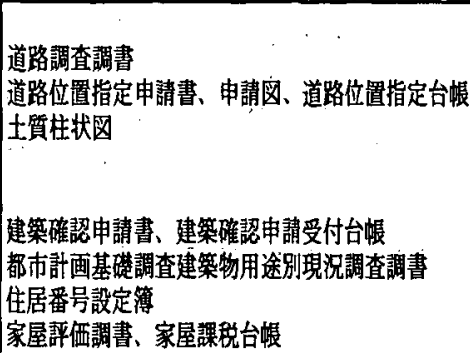 \\
\hline
\end{tabular}

帳属性データまでも一元化することは難しい。なぜ なら、建築確認申請の際の建築主、住居番号設定の 際の所有者・管理人・占有者、家屋課税の対象とな る所有者は必ずしも一致しないからである。同様 に、建築確認申請受付業務では建築基準法別表第 2 に揭載された建築物用途により、建築物用途別現況 調査では都道府県知事の定めた分類により、家屋課 税台帳では不動産登記法施行令第 6 条の建物の種類 により、建築物の用途が分類されている。各法令の 目的や規制内容などは異なるため、それぞれの業務 の形態も異なっている。

しかし、図形データを共通化するだけでも様々な 効果が期待される。建築指導担当部署では工事完了 検查のため、住居表示管理部署では住居番号設定の ため、固定資産税担当部署では家屋の評価のため、 現地調查を行っている。最初に現地調查を行う建築 指導担当部署が、建築物の位置や各階平面図、現地 調查結果などの情報を数值化し、これを他の部署へ 提供することにより、各部署の現地調查事前資料の 作成を省力化することができる。また、都市計画担 当部署では建築物用途別現況図作成や用地買収業務 の効率化、固定資産税担当部署では課税もれの防止 の効果が期待される。このように新築や增築がされ た建築物の図形データの共通化だけでも従来の業務 を効率化することができる。しかし、建築確認受付 台帳や家屋課税台帳については地図を作成していな い市町村が多ので、既存建築物を含む全ての建築物 の図形データと台帳等の属性デー夕を対応させる場 合には多くの労力を要する（注 2）。

このように、建築物に関する台帳属性デー夕まで
も完全に一元化することは困難であるが、部署相互 のデータ提供により各部署の業務の効率化を図るこ とは可能である。システムを構筑する際には、無理 なテータの一元化を図るのではなく、それぞれの業 務に関する法令の目的やその内容、業務の進め方を 充分に調查し、適切な G I S フフトウェアを選択す るとともに、適切なデータの構成、流通順序、管理 体制を定めることが肝要である。

土地に関する業務において基礎となるのは、地番 図である。固定資産税担当部署では複数の地番図が 使用されていることが多い。地籍調査が終了してい ない市町村では、法務局に設置されている公図の写 しのほか、これを編集した地番図が置かれている。 また、より精度の高い地番図を必要とする都市計画 道路整備担当部署、公園整備担当部署、土地区画整 理事業担当部署などでは、測量図に筆界を割り込ん だ図を作成していることもある。

これらの地番図はそれぞれの業務の目的に応じて 作成されており、図面の作成方法や精度が異なって いる。固定資産税担当部署における画地認定業務や 間口奥行き距離計測業務、各種事業担当部署におけ る用地買収業務、土地区画整理事業担当部署におけ る換地業務などにおいて、どのような地番図を基に どのような業務が行われているかを各市町村におい て充分に調查する必要がある。一般には縮尺1： 2500程度の精度の地番図を整備しシステム化するだ けでも、現地調査事前資料の作成支援、地番を探す 際の索引図としての利用などが可能であると考えら れる。また、各種事業担当部署とも連携をとったシ ステムを構築するには、かなり精度の高い地番図 データの整備が必要になろう。

\subsection{GISのデータ構造}

業務で必要とされる情報はそれぞれ考え方の違い があるため、複数業務で利用可能なデー夕は非常に 少数に限られる。自治体の事例をみると、大きく 2 つのアプローチがあった。

注 2 ：土地の分合筆により地番が変動していること、一 筆内に複数の建築物が存在することがあることから建築 物の図形データと台帳等の属性データを住所照合により 対応させるのは困難である。 
(1)自治体で整備されている最も大きい縮尺の地図 をべースに、その内容を検討して、共通と個別の情 報に分離し、共通部分を全庁という位置づけで整備 をすすめるもの

(2)位置座標、および対応するコード（住居表示 等）とを共通のテーブルとして整備し、統計部局、 各種台帳に記載されている住所コードと結合して利 用し、地形等を背景として利用するもの（住所照 合、あるいは地名辞書)

これまでの自治体の状況を見ると、大多数の自治 体で(1)のアプローチを行っているが、各部門の要求 をすりあわせる際に多大の労力と費用を必要として いる。特に、これまでの紙で表現してきたものと差 異のないものを求めようとすれば、苦労が大きいよ うである。地形データとして、実際に必要な事項と 精度を十分に調整しておかないと、共通デー夕を定 める段階で行き詰まってしまうであろう。

これに比較し、図形処理の上ではやや難点を持つ が、(2)のアプローチは容易に整備を進めることがで き、おおかたの業務では実用上差し支えない。しか し、この方法は、事例が少なく、あまり馴染みがな い。

数少ない事例の一つの市では、地名辞書を住居表 示、土地地番、道路区間切りの 3 種類について整備 し、このコードをキーにして住居表示図、土地地番 図、道路区間切り図のポリゴンを背景として利用で きる。ただし図形演算等の処理はできない。

今後自治体で整備を進める際に、どのようなこと を考虑すべきかについて、米国で進められている空 間デー夕基盤（N S D I ）に関する内容の中から基 盤情報のフレームワーク（参考文献 2 ）を参考に以 下のような点を指摘しておく。

1. 基盤情報は、詳細な属性情報を追加できるた めの空間的参照となる情報でなければならない

2. 他の空間データを追加する際に、参照できる 情報でなければならない

3. 信頼できる情報でなければならない

4. 基盤情報は記号等ではなく実世界の特徵及び 位置を正確に表すものでなければならない

5. 基盤情報から低い解像度、小縮尺の情報を生
成できなくてはならない

6. 基盤情報のデータ作成・更新はできるだけ少 ないコストで行われなければならない

7. 基盤情報は、多数の情報供給源からデータを 取り込むことができなければならない

8. 基盤情報は技術的進歩に適応しなければなら ない

さらに、米国の空間データ基盤として挙げられた 情報項目は以下のものである。

(1)基準点、(2)デジタル正射画像データ（高解像度 衛星デー夕)、(3)標高デー夕、(4)交通（道路網、鉄 道網）デー夕、(5)河川・湖沼デー夕、(6)行政界デー 夕、(7)地籍データ

この内容をわが国の自治体に当てはめて考える と、既に大縮尺（1/2500 1/500）地図整備が進み、 行政内部で利用されていることを前提に、複数業務 利用が可能な共通GISデータは、大縮尺相当の位置 精度を持つ、物理的形状が明確にでき、各部門が共 通に認識できる最小のものとすべきである。

具体的には、次のようなものが対象となるであろ う。基準点、標高デー夕、道路・鉄道デー夕、河 $川 \cdot$ 湖沼・水涯線デー夕、行政界・町丁目デー夕、 家屋デー夕、地籍（地番）データとなるであろう （図 3）。さらに今後、データ作成更新のコストを 削減することを考慮すれば、高解像度衛星画像デー タの利用も取り込むべきであろう。

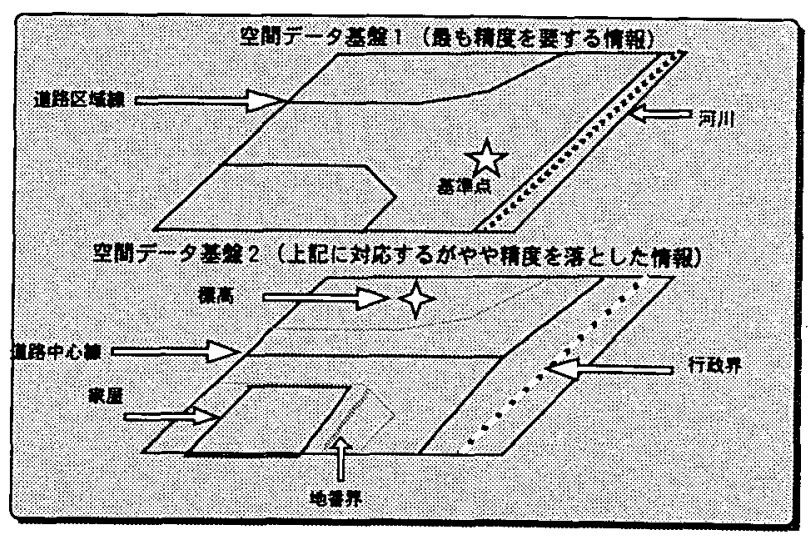

図 3 わが国での空間データ基盤のイメージ

まず第 1 に、すべての基礎となる基準点について 最も高精度に共通のものとすべきである。次に道 
路・河川等の公的なものを共通のものとすべきであ る。これらは、公的機関が管理しており、情報の作 成・更新を公的機関が行っているものである。これ らは、非常に高精度で台帳が作成されており、地域 の骨格となる情報である。行政界・町丁目界は、す でに自治体内では共通のものとして利用されてい る。家屋、地籍は、住民に関するサービスを行う際 に必須となる情報であり、共通のものとして扱うべ きである。ただし、これらを精度高く維持管理する には、非常にコストがかかり、必要最小限の精度之 すべきである。これらを精度の点から整理した私案 を表 4 として示す。

表 4 対象ごとに必要とされる精度

\begin{tabular}{|c|c|c|c|}
\hline 対象 & 形状 & 水平位通精度 & 地形図表現等 \\
\hline 基鹳点 & 点 & $\pm 1 \sim 10 \mathrm{~cm}$ & 真位量 \\
\hline 道路·河川 & 区域缐、中心線 & $\pm 25 \mathrm{c} \mathrm{m}$ & 真形・真幅 \\
\hline 標高 & 点 & $\pm 5 \sim 10 \mathrm{~m}$ & $25 \mathrm{~m}$ 格子点 \\
\hline 家屋 & 外壁、中心点 & $\pm 70 \mathrm{~cm}$ & 真形 \\
\hline 地番 & 区画腺 & 精度を決めない & 現況地形に合致 \\
\hline 铁道 & 区域祢 & $\pm 70 \mathrm{~cm}$ & 真形 \\
\hline 行政界 & 界線 & 精度を決めない & 現況地形に合致 \\
\hline 地籍調查 & 界線 & $\pm 5 \sim 70 \mathrm{~cm}$ & 官民境界のみ报う \\
\hline
\end{tabular}

このように、共通として考えられる対象は、対象 ごとに必要とされる精度が異なっており、作成・更 新費用を考えると、対象ごとに更新できるシステム が必要となろう。特に、これらデー夕更新に当たっ ては、常に精度の高い方を既存データとして扱い、 作業の簡便化を図るべきであろう。また、紙と違 い、自由に拡大縮小ができ、縮尺に合わせた最適の 表現ができるソフトウェアを用いることにより、共 通のデータを利用することが容易になってきてい る。

このような共通化を進める際に最も重要なこと は、それぞれが共通と認める対象の意味する筀間的 領域について、関係する全部門が共通の認識を持た なければ混乱を生じる。例えば、自治体内の共通認 識が進んでいるものとして、行政界が挙げられ、逆 に、前述のとおり家屋等についてはこれからの議論
が必要なものである。さらに各自治体間においても 差があると、大規模地震のような広域的な問題に際 しても、混乱が生じるであろう。従って、この議論 には、全てを自治体に任せられるものではなく各省 庁からの十分な支援により解決可能となるものであ る。

\subsection{GISの費用対効果}

\section{(1)評価の考元方}

公共投資の経済評価については、従来国民経済的 な視点で分析を行う費用便益分析が用いられてき た。しかしながら、自治体におけるG I S 導入に際 して最も重大な問題は、予算当局の納得であり、予 算当局の評価視点が、行政内部の組織効率的なレベ ルにおかれている現状にあっては、分析の視点をプ ロジェクトの運営主体においた経営収支的な手法に よる評価を適用する方が論点が単純化される。

<経営収支分析の特徵〉

・プロジェクト運営主体の経営が分析の視点

・損益が評価指標

・名目額による分析

・市場価格の使用

・外部効果を扱わない分析

・税金、補助金、借入金等を考慮した分析

G I S の導入に際し、予算を取るまでの事前評価 に関心の大半があり、事後評価に関心が向かない場 合がほとんどであることもやむを得ない現状である が、自治体GISは、いったん導入されれば、適用 業務を広げ、機能を充実しながら永続的に発展して いくべきシステムであることから、システム成長の 際に的確な経済評価を実施するためにも、どのよう な機能がどのように役だったか、何が機能として不 足だったかなど機能面からの事後評価が不可欠であ ることを指摘しておきたい。

(2)費用分析

G I S 導入に関わる費用として投資費、運用費、 研究開発費の規模および発生時期を明らかにしなけ ればならない。投資費としては、システム設計費、 情報機器等購入費、ソフトウェア購入費、ソフト ウェア開発費、工事費、データ作成費等がまた、運 
用費としては情報機器等リース料、ソフトウェア・ デー夕等使用料、データ更新費、要員教育費、消耗 品費等が挙げられる。

費用分析における注意点は次の通りである。

(1)プロジェクトライフの適切な設定

(2)費用発生パターンの適切な想定

(3)既投入費用を除く、今後必要な費用を対象

(3)効果分析

G I Sがもたらす効果を分析するためには、まず 発生する可能性のある効果を網羅的に洗い出し、整 理する事が必要である。その中で定量化できるもの について定量的な分析を行う。効果の項目としては 次のようなものが挙げられる。

・行政事務の効率化

・行政水準の向上

-人的資源の有効活用

・オフィススペースの有効活用

・データ管理の高度化

・市民サービスの向上

効果の定量化について最も典型的な効果項目の一 つである基本地図作成業務の重複排除を例にとる と、作成地図の減少枚数に 1 枚あたりの作成時間を 乗じ、さらに時間あたりの人件費を乗じて金銭尺度 に変換するような方法が採られる場合が多い。その 他検索時間や印刷時間の短縮化、保管スペースの節 約、外部委託費の節約、交付税収入の增加等が定量 的に分析される。費用分析と同様効果分析の際の注 意点を挙げると次の通りである。

(1)対象業務範囲に対応した効果の評価

(2)定性効果を含む網羅的な効果項目のリスト

アップ

(3)プロジェクトライフに対応した効果発生パ

ターンの想定

(4)金銭尺度での定量化

(4)費用対効果の評価

費用対効果でみる G I S 導入プロジェクトの評価 は、プロジェクトライフを通じた損益で行う。想定 したプロジェクトライフの中で定量効果の総計が費 用の総計を上回れば、G I S 導入プロジェクトが有 効であると判断される。ただし G I S 導入が問題解
決の方法として最適であるか否かは議論していない ことおよび、比較の対象が導入前の状態ではなく、 G I S を導入しなかった場合の将来像である点に注 意が必要である。ただし、G I S 導入に代わる業務 効率化等の代替案がない場合には、導入前の状況が 将来に渡って続くと考えても差し支えない。

\subsection{GISの推進組織と要員教育}

もう一つの観点として、自治体内での G I S の導 入・推進体制と共通利用の関連について要員教育の 問題も含めて考察した。本調查で得られた22自治体 からのG I S 導入時の計画報告書の内容と、その中 で複数課での利用または総合型システムが計画され ておりシステムの開発段階がほぼ等しい（最初の導 入システムが稼働、次段階を開発中）と思われる4 つの自治体（以下A市、B市、C市、D市とする） の担当者への電話インタビュー結果（1995年 8 月下 旬実施）とにより、要点をまとめると以下の 4 点の とおりである。

(1)共有・統合型のシステムを意図する場合、導入 計画段階で、全庁的レベルでのG I Sニーズに関す るアンケートやヒアリング調查が必須であり、計画 報告書を頂いたほとんどの自治体で行われている。

(2)共有・統合型のシステムに向かう場合、少なく とも地図データついては、専門の課が中心になり一 元管理を行いサーバー役を担う必要がある。例え ば、計画書段階ではこのことを明示していないA市 でも、実際には導入のプロセスで情報管理課を設置 している。また、B市では庁内L A Nがすでに使わ れているが、利用各課で個別システムの導入が進行 したためソフトウェアが異なるという問題が生じ、 データの共通利用は今のところなされておらず、情 報管理課にサーバーを置くことを検討中という。こ れらの事実からも、中心課の存在意義は大きいと言 える。複数課にシステムを導入すれば “自然に” データの共通利用が進むと考えるのは、インタ ビューした自治体の実態からみて幻想に過ぎない。

(3)中心課に必要とされる性格は、情報技術の専門 スタッフを擁していること、導入当初からシステム の利用度が高いこと、L A Nの存在する場合には 
ネットワーク上の中心性を有すること等が挙げられ る。一般的に、「情報管理課」のような専門課に託 される場合が多いが、C市では、最初に固定資産税 管理システムが稼働した税務課がその後も推進体制 の中心となるなど、自治体の状況にもよっている。

(4)導入計画段階ではほとんど意識されていない が、導入部署が増えるにつれ、要員教育は大きな課 題となっている。事務系職員のほとんどがC OBO Lを扱えるという過去の研修の蓄積のあるA市で も、GI S 導入に伴うEWSの扱い等は新たにメー カー研修によって対応せざるを得ない状況となって いる。導入されたシステムを実際に扱えるのは中心 課の一部スタッフのみで、組織的な教育体制はまだ 立ち上がっていないというD市のような状況が一般 的で、中心課のスタッフが必要に応じて個々に教示 しているというのが実態である。要員教育に必要な 要素としては、G I Sの基礎概念、ソフトウェアの 具体的操作の他に、データの共有化に向けてシステ ム本体やネットワーク管理の基礎も今後重要となる ことが予想される。

\section{4. おわりに}

GISに関する紹介、教科書、実例も増えて来た が、自治体業務への適用に直接利用できるものは少 なく、導入に伴う困難さが解決されていないように 見える。導入の意欲を持つ自治体にとって、技術的 問題、財政的問題、組織的問題を一つずつ解決しな ければならず、導入自治体のレポートからは、その 非常な努力がうかがえる。われわれ自治体SIGで は、こうした苦労を少しでも手助けできるマニュア ルを作るべく作業を進めている。

自治体にGISを導入する苦労を軽減する抜本的解 決には、自治体内の努力では限界があり、今春学会 が提言した共通の空間デー夕基盤整備といつた国の 政策も必要である。今後、本SIGは、導入マニュア ルの内容を深めるとともに、国の政策に対しても、 有効な働きをして行きたいと考えている。

\section{参考文献}

田中公雄他、(1995) 自治体におけるGIS取り組み動 向、「GIS-理論と応用小、3(1).

F.G.D.C.,(1995.4) Development of a National Digital Geospatial Data Framework. 